\title{
PENGARUH GAYA BELAJAR DAN STRATEGI PEMBELAJARAN TERHADAP HASIL BELAJAR AL-QUR'AN MAHASISWA UIN MAULANA MALIK IBRAHIM MALANG
}

\author{
I'anatut Thoifah \\ Universitas Muhammadiyah Malang \\ thoifah@umm.ac.id
}

\begin{abstract}
Abstrak: Penelitian ini bertujuan untuk mengetahui ada atau tidaknya interaksi antara gaya belajar dan strategi pembelajaran terhadap hasil belajar Al-Qur'an mahasiswa semester satu Ma'had al-Jami'ah UIN Maulana Malik Ibrahim Malang. penelitian ini menggunkan metode kuantitatif dengan desain faktorial 2x2. Sampel penelitian sebanyak 40 mahasiswa UIN Maulana Malik Ibrahim Malang yang dipilih menggunakan teknik purposive dan random dari populasi semua mahasiswa,dipilih menjadi dua kelompok, yaitu kelompok eksperimen dan kelompok kontrol. Adanya pengaruh dan tidaknya penelitian ini dinilai dari hasil belajar Mahasiswa dan dinilai menggunakan instrumen untuk mengklasifikasikan gaya belajar mahasiswa. Penilain mengukur aspek tajwid al-Qur'an. Nilai yang diperoleh dengan menggunakan SPSS statistic 21 menghasilkan hasil analisis yang menunjukkan bahwa ada perbedaan hasil belajar al-Qur'an antara kelompok mahasiswa yang memiliki gaya belajar field independent dan mahasiswa yang memiliki gaya belajar field dependent, begitu juga ada perbedaan mahasiswa yang belajar dengan strategi pembelajaran musik dan yang belajar dengan strategi pembelajaran konvensional, namun tidak terdapat interaksi antara gaya belajar dan strategi pembelajaran terhadap hasil belajar al-qur'an mahasiswa.
\end{abstract}

Kata kunci: Gaya Belajar, Strategi Pembelajaran, dan Hasil Belajar

\begin{abstract}
Abstrak: This study aims to investigate the interaction of learning style and learning strategies towards the result of learning Al Qur'an among freshmen of Ma'had al-Jami'ah UIN Maulana Malik Ibrahim Malang. A quantitative method with $2 \times 2$ factorial design was used in this study. The samples of this study were 40 students of UIN Maulana Malik Ibrahim Malang who were selected by using random purposive technique sampling. They were classified into two groups; experimental and control groups. In the process of analysis, the students' score of learning Quran in terms of tajwid were correlated with the grouped students based on their learning style and learning strategies. The result of this study showed that there was a different result of learning Quran between the students with field independent learning style and field dependent learning style. Besides, there was also a different result of learning Quran between the students with musical and conventional learning strategy. However, there was no interaction between learning style and learning strategies towards the students' result of learning Qur'an.
\end{abstract}

Keywords: learning styles, learning strategies, and the results of the Study 


\section{Pendahuluan}

Bangsa Indonesia sedang menghadapi krisis multidimensional. Dari hasil berbagai kajian disiplin dan pendekatan, tampaknya ada kesamaan pandangan bahwa segala macam krisis itu berpangkal dari krisis akhlak atau moral serta masih banyaknya peserta didik muslim yang tidak mampu membaca al-Qur'an. Krisis ini, secara langsung atau tidak, berhubungan dengan pendidikan. Kontribusi pendidikan dalam konteks ini adalah pada pembangunan mentalitas manusia yang merupakan produknya. Dan sementara pihak menyebutkan bahwa krisis tersebut karena kegagalan pendidikan agama, termasuk didalamnya pendidikan agama Islam. Untuk mengantisipasi berbagai krisis tersebut, maka pembelajaran agama Islam di sekolah maupun perguruan tinggi harus menunjukkan kontribusinya. Hanya saja perlu disadari bahwa selama ini terdapat berbagai kritik terhadap pelaksanaan pendidikan agama Islam yang sedang berlangsung.

Muchtar Buchori dalam Muhaimin menilai pendidikan agama masih gagal. Kegagalan ini disebabkan karena dalam prakteknya pendidikan agama hanya memperhatikan aspek kognitif semata dari pertumbuhan kesadaran nilai-nilai agama, dan mengabaikan pembinaan aspek afektif dan konatif-volatif, yakni kemauan dan tekad untuk mengamalkan nilai-nilai ajaran agama. Dengan perkataan lain, pendidikan agama lebih berorientasi pada belajar tentang agama, dan kurang berorientasi pada belajar bagaimana cara beragama yang benar. Akibatnya, terjadi kesenjangan antara pengetahuan dan pengamalan, antara gnosis dan praxis dalam kehidupan nilai agama. Disamping itu, Rasdijanah mengemukakan salah satu kelemahan dari pendidikan agama Islam di sekolah, baik dalam pemahaman materi pendidikan agama Islam maupun dalam pelaksanaanya, yaitu orientasi mempelajari Al-Qur.an masih cenderung pada kemampuan membaca teks, belum mengarah pada pemahaman arti dan penggalian makna.

Dari beberapa faktor diatas, UIN Maulana Malik Ibrahim hadir untuk memenuhi dan melengkapi model dan strategi pembelajaran yang membantu guru dalam menyampaikan materi. Mengingat, keberhasilan pembelajaran sangat ditentukan oleh guru, dan memudahkan siswa dalam belajar.

Miarso (2004: 4) mendefinisikan belajar adalah belajar itu terjadi sebagai akibat adanya pengkondisian lingkungan yang diikuti dengan adanya penguatan. Aliran keprilakuan menganggap bahwa belajar adalah perubahan prilaku yang dapat diamati. Sementara Winkel (1996: 52) menyatakan bahwa, belajar sebagai suatu aktivitas psikis atau mental yang berlangsung dalam interaksi dengan lingkungan, yang menghasilkan perubahan-perubahan sains 
pengetahuan, pemahaman, nilai, dan sikap.

Sedangkan Hilgard dan Bower mengemukakan bahwa belajar berhubungan dengan perubahan tingkah laku seseorang terhadap suatu situasi tertentu yang disebabkan oleh pengalamannya yang berulang-ulang dalam situasi dimana perubahan tingkah laku itu tidak dapat dijelaskan atau dasar kecenderungan respon pembawaan.

Senada dengan pendapat tersebut Gagne (1988: 17-18) mengatakan bahwa belajar adalah suatu proses yang dapat dilakukan oleh mahluk hidup dan memungkinkan prilakunya berubah secara cepat seperti adanya perubahan-perubahan prilaku pada setiap pembelajar.

Berdasarkan beberapa penjelasan di atas dapat didefinisikan bahwa belajar pada hakekatnya adalah proses perubahan prilaku siswa dalam bakat pengalaman dan pelatihan. Artinya tujuan kegiatan belajar mengajar ialah perubahan tingkah laku, baik yang menyangkut pengetahuan, keterampilan, sikap, bahkan meliputi segenap aspek pribadi.

Salah satu kesuksesan mahasiswa dapat dilihat dari hasil belajar. Hasil belajar pada dasarnya merupakan suatu kemampuan yang berupa keterampilan dan perilaku baru sebagai akibat latihan atau pengalaman setelah mengikuti proses pembelajaran. Dalam hal ini (nasrun, 2013) berpendapat bahwa hasil belajar merupakan hasil akhir pengambilan keputusan mengenai tinggi rendahnya nilai yang diperoleh selama mengikuti proses pembelajaran.

Hasil belajar yang dicapai oleh siswa ditunjukkan oleh perubahan-perubahan dalam bidang pengetahuan, pemahaman, keterampilan, analisis, sintesis, tes serta nilai dan sikap. Adanya perubahan itu tercermin dalam prestasi belajar yang diperoleh siswa. Dalam hl ini Briggs (1979: 149) memberikan pengertian bahwa hasil belajar adalah seluruh kecakapan dalam segala hal yang diperoleh melalui proses belajar mengajar di sekolah yang dinyatakan dengan angka dan diukur dengan menggunakan tes hasil belajar. Senada dengan pendapat tersebut, Adkins (1974: 3) mendefinisikan hasil belajar sebagai kemampuan yang dapat diukur secara langsung dengan tes.

Romiszowski membagi hasil belajar menjadi empat ranah, yaitu; 1) kognitif; 2) psikomotorik; 3) reaksi emosional; dan 4) interaksi; yaitu keterampilan menerima dan menyampaikan informasi. (Romiszowski, 1981: 253)

Menurut Gagne hasil belajar adalah kapabilitas yang digolongkan atas: 1) informasi verbal; kemampuan menyatakan kembali informasi yang diperoleh dari proses belajar; 2) keterampilan 
intelek; melalui proses belajar seseorang akan mampu berfungsi dengan baik dalam masyarakat; 3) keterampilan motorik; kemampuan mengurai berbagai jenis keterampilan gerak; 4) sikap; kapabilitas yang mempengaruhi pilihan tentang tindakan mana yang akan dilakukan; dan 5) siasat kognitif; kapabilitas yang mengatur cara bagaimana peserta didik belajar mengelola belajarnya. (Gagne, 1983: 3)

Gronlund mengelompokkan hasil belajar atas;

pengetahuan; (2) pemahaman; (3) keterampilan berpikir; (4) keterampilan dalam penampilan; (5) keterampilan berkomunikasi; (6) keterampilan berhitung; (7) keterampilan belajar sambil bekerja; (8) keterampilan bersosialisasi; (9) sikap; (10) minat; (11) apresiasi; dan (12) penyesuaian diri (Gronlund, 1978: 3) Sedangkan Bloom mengelompokkan hasil belajar atas tiga ranah, yaitu: (1) ranah kognitif; berhubungan dengan perubahan pengetahuan; (2) ranah afektif; berhubungan dengan perkembangan atau perubahan sikap sebagai hasil dari proses belajar, dan (3) ranah psikomotorik; berhubungan dengan penguasaan keterampilan motorik. (Bloom, 1970: 7-9)

Dari uraian di atas dapat disimpulkan bahwa hasil belajar adalah kemampuan yang diperoleh siswa melalui proses belajar mengajar di sekolah dalam kurun waktu tertentu yang meliputi domain kognitif, afektif, dan psikomotorik yang dinyatakan dengan angka dan diukur dengan menggunakan tes hasil belajar.

Salah satu faktor yang mempengaruhi hasil belajar adalah Strategi pembelajaran yang merupakan salah satu komponen pembelajaran yang harus mendapatkan perhatian khusus dalam melaksanakan proses pembelajaran di sekolah sehingga tujuan pembelajaran dapat tercapai. Menurut Uno strategi pembelajaran adalah cara-cara yang akan digunakan oleh pemelajar untuk memilih kegiatan belajar yang akan digunakan selama proses pembelajaran. Pemilihan tersebut dilakukan dengan mempertimbangkan siatuasi dan kondisi sumber belajar, kebutuhan dan karakteristik peserta didik yang dihadapi untuk mencapai tujuan pembelajaran. (Uno. 2007: 3)

Dick \& Carry (2006: 235) mengemukakan strategi pembelajaran terdiri atas seluruh komponen materi pembelajaran dan prosedur atau tahapan kegiatan belajar yang digunakan oleh pemelajar dalam rangka membantu pebelajar untuk mencapai tujuan pembelajaran tertentu.

Hal ini menunjukkan, bahwa strategi pembelajaran bukan hanya terbatas pada prosedur atau tahapan kegiatan belajar, melainkan juga termasuk pengaturan materi atau paket program pembelajaran yang akan disampaikan kepada pebelajar. 
Berdasarkan para pendapat ahli di atas, maka dapat disimpulkan bahwa strategi pembelajaran merupakan pola umum kegiatan pembelajaran, rangkaian perbuatan guru dan siswa dalam mewujudkan peristiwa pembelajaran yang efektif untuk mencapai suatu tujuan pembelajaran.

Sedikitnya ada dua kategori yang akan dibahas dalam permainan music: menunjukkan pada hasil penggunaan suatu alat (instrumen) yang menghasilkan bunyi dan musik yang dihasilkan dari unsur manusia sendiri yaitu berupa nyanyian.

Masing-masing mempunyai kegunaan dan tuntutan keahlian yang berbeda. Bagi bayi, anak-anak atau orang dewasa contohnya Teaching Strategies for Musical Intelligence. Musik berpengaruh pada guru dan dan pelajar. Sebagai seorang guru, anda dapat menggunakan musik untuk menata suasana hati, mengubah keadaan mental siswa. Musik dapat membantu siswa mesuk ke keadaan belajar optimal, music juga emungkinkan anda membangun hubungan dengan siswa melalui music, anda dapat "berbicara dalam bahasa mereka". (Lozano, 1979)

Musik berpengaruh kuat pada lingkungan belajar. Penelitian menunjukkan bahwa lebih mudah dan cepat jika pelajar berada dalam kondidi santai dan reseptif. Efek suara membantu menciptakan lingkungan bermain, minat dan pertunjukan, dan dapat menyoroti halhal penting. Lagu tema kuis televisi dapat menambah kesan permainan dan ketegangan. Putar lagu tema "Famili 100" saat pelajar bersiap-siap menjawab.

Sedang strategi konvensional menurut Menurut P. R. Wallace (dalam Sunarto: 2009) suatu pendekatan pembelajaran dikatakan sebagai pendekatan pembelajaran yang konvensional apabila mempunyai ciri-ciri sebagai berikut:

1. Otoritas seorang guru lebih diutamakan dan berperan sebagai contoh bagi murid-muridnya.

2. Perhatian kepada masing-masing individu atau minat siswa sangat kecil.

3. Pembelajaran di sekolah lebih banyak dilihat sebagai persiapan akan masa depan, bukan sebagai peningkatan kompetensi siswa di saat ini.

4. Penekanan yang mendasar adalah pada bagaimana pengetahuan dapat diserap oleh siswa dan penguasaan pengetahuan tersebutlah yang menjadi tolok ukur keberhasilan tujuan, sementara pengembangan potensi siswa diabaikan.

Dalam hal ini seorang guru dituntut untuk kreatif dan memperhatikan strategi pembelajaran yang digunakan dan dapat 
memilahnya manakah yang paling sesuai untuk diterapkan pada materi yang diajarkannya. Salah satu strategi pembelajaran yang sudah sering digunakan oleh guru adalah model pembelajaran konvensional.

Jadi dalam strategi pembelajaran konvensional kegiatan guru yang utama adalah menerangkan dan siswa mendengarkan atau mencatat apa yang disampaikan guru. Guru biasanya mengajar dengan berpedoman pada buku teks atau LKS, dengan menggunakan metode ceramah, ekspositori, latihan dan kadang-kadang tanya jawab. Tes atau evaluasi dengan maksud untuk mengetahui perkembangan penguasaan siswa terhadap materi yang diajarkan biasanya jarang dilakukan. Siswa harus mengikuti cara belajar yang dipilih oleh guru dengan patuh mempelajari urutan yang ditetapkan guru, dan kurang sekali mendapat kesempatan untuk menyatakan pendapat. Siswa cenderung belajar individual karena tidak banyak kesempatan untuk bekerja sama dengan temannya dalam rangka saling berbagi, saling membantu, saling mengkoreksi, dan lain-lain.

Hal tersebut disebabkan karena dalam model pembelajaran konvensional guru lebih aktif dari pada siswa, selain itu tidak ada pembentukan kelompok-kelompok heterogen dalam kegiatan pembelajaran, sehingga cenderung timbul kemungkinan siswa menjadi lebih pasif dan malu untuk menanyakan kepada guru mengenai hal-hal yang dianggapnya masih sulit sedangkan menanyakan kepada temannya yang lain tidak ada kesempatan.

Sedangkan otak siswa diibaratkan sebagai botol kosong yang siap untuk diisi oleh air, maka untuk mengisi otak siswa tersebut guru memberikan seluruh ilmu pengetahuan kepada siswa dan siswa harus siap menerima seluruh ilmu pengetahuan yang diberikan kepadanya. Disamping itu, guru jarang mengajar siswa untuk menganalisa secara mendalam tentang suatu konsep dan jarang mendorong siswa untuk menggunakan penalaran logis yang lebih tinggi seperti kemampuan membuktikan atau memperlihatkan suatu konsep.

Dari uraian di atas, dapat diambil suatu kesimpulan bahwa yang dimaksud dengan pembelajaran al-Qur'an dengan menerapkan startegi pembelajaran konvensional adalah suatu kegiatan belajar mengajar yang selama ini kebanyakan dilakukan oleh guru yang di dalamnya aktivitas guru mendominasi kelas, ceramah dan latihan. Siswa hanya menerima saja apa-apa yang disampaikan oleh guru, begitupun aktivitas siswa untuk menyampaikan pendapat sangat kurang, sehingga siswa menjadi pasif dalam belajar. Adapun dalam pembelajaran yang menggunakan model pembelajaran ini upaya pengembangan kompetensi siswa masih belum terlalu diperhatikan. Murid hanya menerima saja apapun informasi yang diberikan oleh 
guru tanpa diberikan kesempatan ataupun diarahkan untuk mengembangkan kemampuannya dalam menganalisis hal-hal yang berhubungan dengan soal-soal yang sedang dipelajari.

Strategi akan memberikan dampak positif yakni keberhasilan siswa jika strategi yang digunakan sesui dengan Gaya belajar siswa yakni gaya atau cara seseorang dalam menerima dan mengolah informasi. Sejalan dengan pendapat tersebut, Gunawan (2003: 139) mengatakan bahwa gaya belajar adalah cara yang lebih disukai dalam melakukan kegiatan berpikir, memproses dan mengerti suatu informasi. Misalnya jikat kita ingin mempelajari suatu tanaman, apakah kita lebih suka nonton vodeo soal tanaman, mendengarkan ceramah, membaca buku ataukah kita bekerja langsung diperkebunan atau mengunjungi kebun raya.

Gaya belajar biasanya berkembang perlahan-lahan mengikuti pengalaman. Gaya belajar tidak dapat berubah karena latihan tertentu atau pengajaran tertentu, tetapi berubah mengikuti kematangan atau kedewasaan.

Menurut Kogan (dalam Slavin, 2008: 168) menjelaskan bahwa, gaya belajar adalah orientasi untuk mendekati tugas-tugas belajar dan mengolah informasi dengan cara-cara tertentu. Gaya belajar dibagi atas dua yaitu field independent dan field dependent. Perbedaan pandangan terhadap gaya belajar tersebut, dikemukakan oleh Nasution bahwa gaya belajar digolongkan menurut yang ada kaitannya dengan proses belajar mengajar. Dari berbagai penggolongan dapat diambil tiga gaya belajar diantaranya, gaya belajar field dependent- field independent, gaya belajar impulsif-reflektif dan gaya belajar preseptif/reseptifsistematis/intuitif (Nasution, 2009: 94).

Berdasarkan berbagai pendapat yang telah dikemukakan di atas, maka yang dimaksud dengan gaya belajar adalah pola strategi khusus yang digunakan oleh setiap individu siswa dalam menghadapi dan mengambil strategi belajar, yang meliputi bagaimana mengumpulkan informasi, memproses informasi, dan membuat keputusan yang dirasakan nyaman dan sesuai sehingga siswa menjadi lebih senang belajar. Dan yang dimaksud dengan gaya belajar field independent dalam penelitian ini adalah pola strategi yang lakukan oleh siswa dalam mengumpulkan kegiatan belajar yang tidak dipengaruhi oleh lingkungan. Sedangkan field dependent dalam penelitian ini adalah pola strategi yang dilakukan oleh siswa dalam mengumpulkan informasi, memproses informasi, dan membuat keputusan dalam kegiatan belajar yang dipengaruhi oleh lingkungan atau bergantung pada lingkungan. 


\section{METODOLOGI PENELITIAN}

Penelitian ini bertujuan untuk mengetahui pengaruh gaya belajar dan strategi pembelajaran dalam rangka perbaikan kualitas belajar al-Qur'an mahasiswa UIN Maulana Malik Ibrahim Malang. Pendekatan yang digunakan adalah kuantitatif dengan metode ex-post facto dengan desain fktorial $2 \times 2$.

Populasi yang digunakan dalam penelitian ini adalah seluruh mahasiswa mabna Fatimah Az-Zahra UIN Maulana Malik Ibrahim Malang. Adapun sampel yang digunakan adalah mahasiswa kelas Qiro'ah UIN Maulana Malik Ibrahim Malang sebanyak 40 mahasiswa, yang dipilih menggunakan teknik purposive dan random dari populasi semua mahasiswa, dipilih menjadi dua kelompok, yaitu kelompok eksperimen dan kelompok kontrol. Adanya pengaruh dan tidaknya penelitian ini dinilai dari hasil belajar Mahasiswa dan dinilai menggunakan instrumen untuk mengklasifikasikan gaya belajar mahasiswa. Penilain mengukur aspek tajwid al-Qur'an. Nilai yang diperoleh dengan menggunakan SPSS statistik.

\section{HASIL PENELITIAN}

Untuk mempermudah memahami hasil penelitian, peneliti mencoba memaparkan hasil penelitian ini, bahwa Hasil belajar alQur'an mahasiswa yang mempunyai gaya belajar dependen dan independen serta yang menggunakan strategi pembelajaran music dan konvensioanal dapat disajikan pada Tabel 1.

\begin{tabular}{|c|c|c|c|c|c|c|c|c|c|c|}
\hline \multicolumn{11}{|c|}{ Independent Samples Test } \\
\hline & & \multicolumn{2}{|c|}{$\begin{array}{l}\text { Levene's Test for Equality of } \\
\text { Variances }\end{array}$} & \multicolumn{7}{|c|}{ t-test for Equality of Means } \\
\hline & & \multirow[b]{2}{*}{$\mathrm{F}$} & \multirow[b]{2}{*}{ Sig. } & \multirow[b]{2}{*}{$t$} & \multirow[b]{2}{*}{ df } & \multirow[b]{2}{*}{ Sig. (2-tailed) } & \multirow{2}{*}{$\begin{array}{c}\text { Mean } \\
\text { Difference }\end{array}$} & \multirow{2}{*}{$\begin{array}{l}\text { Std. Error } \\
\text { Difference }\end{array}$} & \multicolumn{2}{|c|}{$\begin{array}{l}95 \% \text { Confidence Interval of the } \\
\text { Difference }\end{array}$} \\
\hline & & & & & & & & & Lower & Upper \\
\hline Hasil Belajar & $\begin{array}{l}\text { Equal variances } \\
\text { assumed }\end{array}$ & 4.385 & .049 & 1.056 & 20 & .303 & 6.633 & 6.279 & -6.465 & 19.732 \\
\hline & $\begin{array}{l}\text { Equal variances not } \\
\text { assumed }\end{array}$ & & & 1.106 & 18.224 & .283 & 6.633 & 5.996 & -5.954 & 19.220 \\
\hline
\end{tabular}

Tabel 1. Perbedaan hasil belajar hasil belajar al-qur'an kelas Qiro'ah kelompok mahasiswa yang diajar dengan strategi pembelajaran musik (A1) dan strategi pembelajaran konvensional (A2)

Hasil analisa data dengan menggunakan ANAVA dua jalur pada taraf signifikansi $\alpha=0,05$, tersebut di atas, memberikan nilai $\mathrm{F}_{\text {observasi }}$ $\left(F_{0}\right)=43,85$ lebih besar dari $F_{\text {tabel }}\left(F_{t}\right)=4,35$. Hal ini berarti bahwa $H_{o}$ ditolak. Sebagai konsekuensinya maka $\mathrm{H}_{1}$ diterima. Dengan demikian dapat disimpulkan bahwa hasil belajar al-Qur'an Mahasiswa kelas Qiro'ah yang diberi Strategi pembelajaran Musik lebih tinggi dari hasil belajar al-Qur'an Mahasiswa kelas Qiro'ah yang diberi Strategi pembelajaran konensioanl, dengan kata lain bahwa kelompok $A_{1}>$ 
I'anatut Thoifah - Pengaruh Gaya Belajar dan Strategi Pembelajaran Terhadap Hasil Belajar alQur'an Mahasiswa UIN Maulana Malik Ibrahim Malang

kelompok $\mathrm{A}_{2}$.

\begin{tabular}{|c|c|c|c|c|c|c|c|c|c|c|}
\hline \multicolumn{11}{|c|}{ (2) } \\
\hline & & \multicolumn{2}{|c|}{$\begin{array}{l}\text { Levene's Test for Equality of } \\
\text { Variances }\end{array}$} & \multicolumn{7}{|c|}{ t-test for Equality of Means } \\
\hline & & \multirow[b]{2}{*}{$\mathrm{F}$} & \multirow[b]{2}{*}{ Sig. } & \multirow[b]{2}{*}{$t$} & \multirow[b]{2}{*}{ df } & \multirow[b]{2}{*}{ Sig. (2-tailed) } & \multirow{2}{*}{$\begin{array}{c}\text { Mean } \\
\text { Difference }\end{array}$} & \multirow{2}{*}{$\begin{array}{l}\text { Std. Error } \\
\text { Difference }\end{array}$} & \multicolumn{2}{|c|}{$\begin{array}{l}95 \% \text { Confidence Interval of the } \\
\text { Difference }\end{array}$} \\
\hline & & & & & & & & & Lower & Upper \\
\hline Hasil Belajar & $\begin{array}{l}\text { Equal variances } \\
\text { assumed }\end{array}$ & 1.025 & .324 & 3.949 & 20 & .001 & 19.100 & 4.836 & 9.012 & 29.188 \\
\hline & $\begin{array}{l}\text { Equal variances not } \\
\text { assumed }\end{array}$ & & & 4.058 & 19.804 & .001 & 19.100 & 4.707 & 9.276 & 28.924 \\
\hline
\end{tabular}

Tabel 2. Perbedaan hasil belajar al-qur'an kelas Qiro'ah antara kelompok mahasiswa yang memiliki gaya belajar field independen dan gaya belajar field dependent

Hasil analisa data dengan menggunakan ANAVA dua jalur pada taraf signifikansi $\alpha=0,05$, tersebut di atas, memberikan nilai $F_{\text {observasi }}$ $\left(F_{o}\right)=10,25$ lebih besar dari $F_{\text {tabel }}\left(F_{t}\right)=4,35$. Hal ini berarti bahwa $\mathrm{H}_{o}$ ditolak. Sebagai konsekuensinya maka $\mathrm{H}_{1}$ diterima. Dengan demikian dapat disimpulkan bahwa hasil belajar al-Qur'an Mahasiswa kelas Qiro'ah yang memiliki gaya belajar field independent $\left(\mathrm{B}_{1}\right)$ lebih tinggi dengan siswa yang memiliki gaya belajar field independent $\left(\mathrm{B}_{2}\right)$ dengan kata lain bahwa kelompok $\mathrm{B}_{1}>$ kelompok $\mathrm{B}_{2}$.

\section{Tests of Between-Subjects Effects}

Dependent Variable: Hasil Belajar

\begin{tabular}{|l|r|r|r|r|r|}
\hline Source & $\begin{array}{r}\text { Type III Sum } \\
\text { of Squares }\end{array}$ & df & Mean Square & \multicolumn{1}{c|}{ F } & \multicolumn{1}{c|}{ Sig. } \\
\hline Corrected Model & $2726.273^{\mathrm{a}}$ & 3 & 908.758 & 9.012 & .001 \\
Intercept & 129930.704 & 1 & 129930.704 & 1288.569 & .000 \\
SB & 320.333 & 1 & 320.333 & 3.177 & .092 \\
GB & 1942.259 & 1 & 1942.259 & 19.262 & .000 \\
SB * GB & 334.259 & 1 & 334.259 & 3.315 & .085 \\
Error & 1815.000 & 18 & 100.833 & & \\
Total & 135596.000 & 22 & & & \\
Corrected Total & 4541.273 & 21 & & & \\
\hline
\end{tabular}

a. $\mathrm{R}$ Squared $=.600($ Adjusted $\mathrm{R}$ Squared $=.534)$

Tabel 3. Interaksi antara strategi pembelajaran dengan gaya belajar terhadap hasil belajar al-Qur'an mahasiswa kelas Qiro'ah

Berdasarkan hasil Analisis varian dua jalur diperoleh perhitungan $F_{\text {obserasi }}$ sebesar 3.315 dengan peluang kesalahan 0.85. Bila nilai $F_{\text {obserasi }}$ dikonfirmasi ke $F_{\text {tabel }}$ dengan taraf signifikansi 0.05 (5\%) dimana db 1 untuk pembilang dan 22 
untuk penyebut, diperoleh angka 4.30 pada $F_{\text {tabel }}$ yang berarti $F_{\text {hitung }}$ lebih kecil dari $F_{\text {tabel. }}$. Berhubung peluang kesalahan lebih besar dari taraf signifikansi yang ditetapkan 0.05 maka $H_{0}$ diterima dan $H_{1}$ ditolak, sehingga dapat disimpulkan bahwa tidak terdapat interaksi yang signifikan antara pembelajaran dengan menggunakan strategi musik dalam pengaruhnya terhadap hasil belajar alQur'an.

\section{PEMBAHASAN}

Penelitian ini menunjukkan adanya pengaruh antara mahasiswa yang mempunyai gaya belajar independen dan dependen terhadap hasil belajar, berdasarkan pengolahan data dan analisis data statistik bahwa mahasiswa yang memiliki gaya belajar independen lebih tinggi nilai rata-ratanya dibandingkan dengan mahasiswa yang mempunyai gaya belajar dependen.

Begitu juga dengan strategi pembelajaran yang dilakukan oleh seorang guru memberikan pengaruh terhadap hasil belajar al-Qur'an mahasiswa, strategi yang digunakan disini yaitu strategi musik dan konvensional, bahwa Strategi pembelajaran merupakan salah satu komponen pembelajaran yang harus mendapatkan perhatian khusus dalam melaksanakan proses pembelajaran di sekolah sehingga tujuan pembelajaran dapat tercapai. Dalam hal ini mahasiswa yang belajar dengan menggunakan strategi musik mendapatkan nilai rata-rata lebih tinggi dibandingkan dengan strategi konvensional, hal ini menunjukkan adanya pengaruh yang signifikan antara gaya belajar dan hasil belajar serta strategi pembelajaran terhadap hasil belajar.

Namun demikian, disisi lain penelitian ini memberikan hasil bahwa Tidak adanya interaksi ini menunjukkan bahwa pendekatan musik secara signifikan telah membuktikan bahwa pencapaian hasil belajar mahasiswa yang mempunyai gaya belajar independen maupun dependen berbeda secara signifikan dibandingkan dengan pendekatan konvensional. Dengan kata lain, pendekatan musik dapat diterapkan pada semua kelompok, baik pada kelompok yang mempunyai gaya belajar independen maupun dependen. Jadi, dapat disimpulkan bahwa efektivitas strategi musik tidak tergantung pada gaya belajar mahasiswa yang dimiliki terhadap hasil belajar al-Qur'an. Hasil analisis memang menunjukkan tidak adanya interaksi antara strategi dan gaya belajar namun dalam pembelajaran dengan pendekatan musik mahasiswa merasa lebih nyaman dan menyenangkan sehingga memudahkan mahasiswa untuk memahami materi yang diajarkan. Selain adanya stimulus dari guru, hal ini merupakan salah satu indikator adanya motivasi belajar siswa. 
Penelitian ini tidak terlepas dari keterbatasan peneliti dalam proses melakukan pengumpulan data gaya belajar, oleh karena itu kemungkinan akan berpengaruh terhadap kemurnian hasil yang diperoleh. Selain itu wilayah generalisasi yang terbatas, dikarenakan penelitian ini menggunakan teknik pengambilan sampel yang tersedia dengan pertimbangan-pertimbangan tertentu dari peneliti maka hasil penelitian ini hanya bisa digeneralisasikan pada populasi yang berkarakter sama. Keterbatasan lainnya missal Terdapat variabel lain yang berpengaruh terhadap keberhasilan mahasiswa dalam memecahkan masalah yang tidak diperhatikan secara mendalam pada penelitian ini yaitu: intelejensi, gaya belajar, minat, kepercayaan diri maupun lingkungan belajar yang tidak di control dan juga Data yang seharusnya tidak signifikan melakukan pengulangan namun untuk kepentingan uji hipotesis statistik, data tersebut di normalkan dengan membuang outlier (pencilan).

Meskipun demikian, dengan berbagai keterbatasan penelitian yang tersebut di atas penelitian ini memberikan implikasi positif terhadap pengembangan keilmuan bahwa pendekatan musik memberikan pengaruh terhadap hasil belajar mahasiswa dilihat dari gaya belajarnya. Terbukti dari hasil penelitian yang menunjukkan bahwa mahasiswa yang diajar melalui pendekatan musik memiliki hasil belajar yang berbeda dari mahasiswa yang diajar melalui pendekatan konvensional. terlepas adanya keterbatasan-keterbatasan yang dimiliki. Sehingga menuntut guru untuk mencoba menerapkan berbagai jenis strategi lain yang lebih cocok untuk meningkatkan kemampuan belajar al-Qur'an mahasiswa. Selain itu, perlu ada usaha-usaha yang lebih konkrit dalam meningkatkan motivasi siswa, khususnya pada pembelajaran al-Qur'an sehingga akan meningkatkan kualitas belajar mahasiswa. Selain itu, perlu ada inovasi khusus bagi para guru untuk mengembangkan strategi pembelajaran yang lebih meningkatkan motivasi belajar siswa.

\section{KESIMPULAN}

Berdasarkan analisis data dan pembahasan, maka penelitian ini dapat disimpulkan sebagai berikut:

1. Terdapat perbedaan hasil belajar al-Qur'an mahasiswa kelompok yang diajar melalui pendekatan musik dengan mahasiswa kelompok yang diajar melalui pendekatan konvensional. 
2. Terdapat perbedaan hasil belajar al-Qur'an mahasiswa yang memiliki gaya belajar independen dengan mahasiswa yang memiliki gaya belajar dependen dengan strategi dan konvensional.

3. Tidak terdapat interaksi antara strategi pembelajaran dengan gaya belajar mahasiswa terhadap hasil belajar al-Qur'an (interaksi $A X B$ ).

\section{DAFTAR PUSTAKA}

Adkins, Dorothy C. 1974. Test Construction: Development and Interpreting of Achievement test. Ohio: Merriel Company.

Bloom, Benyamin S. 1970. Taxonomy of Educational Objective. London: Longman.

Borich, Gary D. 1996. Effective Teaching Methods. New Jersey: PrenticeHall.inc

Briggs, Leslie. J. (ed), 1979. Instructional Design: Principles and Application. Englewood Cliffs, New Jersey: Prentice-Hall Inc.

Bruner, Jerome. 1974. Toward a Theory of Instruction, Dikutip langsung oleh Glenn E. Snelbecker, Learning Theory, Instructional Theory and Psychoeducational Design. New York: McGraw Hill Book Company.

Gagne, Robert M. 1983. The Condition of Learning. New York: Hot Rinehart and Winston Inc.

1988. Prinsip-Prinsip Belajar Untuk Pengajaran. terjemahkan: Abdillah Hanafi dan Abdul Manan. Florida.

Gunawan, Adi W. 2003. Genius Learning Strategy: Petunjuk Praktis Untuk Menerapkan Accelerated Learning. Jakarta: Gramedia Pustaka. 
Hamalik, Oemar. 2008. Manajemen Pengembangan Kurikulum. Bandung: Sekolah Pasca Sarjana Universitas Pendidikan Indonesia dan PT. Rosdakarya.

Miarso, Yusuf hadi. 2004. Menyemai Benih Teknologi Pendidikan. Jakarta: Kencana.

Nasution, S. 2009. Belajar dan Mengajar. Jakarta: PT. Bumi Aksara.

Romiszowski, A.J. 1981. Designing Instructional System Decision in Course Planning. New York: Nicholas Publishing Company.

Santrock, John. W. 2009. Educational Psikolog. Jakarta: Salemba Humanika.

Slavin, Robert E. 2008. Psikologi Pendidikan; Teori Dan Praktek. Terjemahan: Marianto Samosir. Jakarta: PT. Macana Jaya Cemerlang.

Uno, Hamzah B. 2007. Model Pembelajaran Menciptakan Proses Belajar Mengajar yang Kreatif dan Efektif. Jakarta: PT. Bumi Aksara.

Winkel., W.S. 1996. Psikologi Pengajaran. Jakarta: Grasindo.

Wolfolk, Anita E. 1993. Educational Psikologi, Boston: Allyn \& bacon, 1993..

Wolter, Dick dan L. Carry, 2006. The Systematic design of instruction. New York: Harper Collins. 